\title{
Adoption of Scientific Health Care Practices of Goat Owners in Chittorgarh District of Rajasthan, India
}

\author{
Anil Mordia $^{1}$ *, M.C. Sharma ${ }^{2}$ and Sunil Kumar ${ }^{2}$ \\ ${ }^{1}$ Livestock Research Station, Dag, Jhalawar, India \\ ${ }^{2}$ Department of Livestock Production Management, College of Veterinary and Animal \\ Science, Navania, Udaipur-313601, Rajasthan University of Veterinary and Animal Sciences, \\ Bikaner-334001, Rajasthan, India
}

Corresponding author

\begin{tabular}{|c|c|}
\hline & A B S T R A C T \\
\hline & \multirow{6}{*}{$\begin{array}{l}\text { Livestock play a vital role in the agriculture and rural economics of the developing world. } \\
\text { Animal husbandry is a major economic activity of the rural peoples, especially in the } \\
\text { Chittorgarh district of Southern Rajasthan. A field survey was conducted to study adopted } \\
\text { scientific goat health care practices of } 120 \text { respondents of } 8 \text { villages of Chittorgarh and } \\
\text { Kapasan tehsils of Chittorgarh district of Rajasthan were interviewed. Adoption is a mental } \\
\text { process and depends on many factors viz., awareness knowledge, innovativeness and } \\
\text { characteristics of an innovations etc. The study revealed that high adoption was noticed in } \\
\text { practicing isolation of sick animals from flock was obtained overall first rank with } 81.94 \\
\text { MPS. In which level of adoption Chittorgarh tehsil obtained first rank with } 95.56 \text { MPS and } \\
\text { Kapasan tehsil obtained second rank with } 68.33 \text { MPS in the study area. The disposal of } \\
\text { placenta by recommended method obtained overall second rank with } 73.89 \text { MPS in which } \\
\text { level of adoption Chittorgarh tehsil obtained third rank with } 73.89 \text { MPS and Kapasan tehsil } \\
\text { obtained first rank with } 73.89 \text { MPS in all categories. The overall third rank was obtained } \\
\text { by control of in house flies/mosquitoes by suitable disinfectants with } 67.78 \text { MPS. Lower } \\
\text { adoption was found that Grooming practice for protection of goat from parasites obtained } \\
\text { thirteenth in the priority of adoption with } 33.61 \text { MPS respectively in the study area. }\end{array}$} \\
\hline & \\
\hline $\begin{array}{l}\text { Adoption, Goat } \\
\text { owners, Health } \\
\text { care, Practices, } \\
\text { Chittorgarh and } \\
\text { Rajasthan }\end{array}$ & \\
\hline Article Info & \\
\hline $\begin{array}{l}\text { Accepted: } \\
\text { 17 June } 2018 \\
\text { Available Online: } \\
\text { 10 July } 2018\end{array}$ & \\
\hline & \\
\hline
\end{tabular}

\section{Introduction}

Livestock sector is significantly contributing to the national economy and its growth rate is continuously increasing.

Livestock sector constitutes an important component of agricultural economy of developing countries, a contribution that goes beyond direct food production and includes multipurpose products and uses, such as skin, feather, fibre, manure for fertilizer and fuel, power and transportation, as barter product in societies where there is no circulation of currency (Satyanarayan et al., 2010).

Animal husbandry is a major economic 
activity of the rural peoples, especially in the Chittorgarh district of Southern Rajasthan. Development of livestock sector has a significant beneficial impact in generating employment and reducing poverty in rural areas. More than 80 per cent rural families keep livestock in their households. Contribution of animal husbandry sector to the GDP of the state has been estimated to be around 9.16 per cent. About 35 per cent of the income to small and marginal farmers comes from dairy and animal husbandry (SourceAnimal Husbandry Department, Rajasthan 2016).

The world population of goat is estimated to be 921 million (UN Food and Agriculture Organization, FAOSTAT-2012). More than 95 per cent of the goat population is found in developing countries. In terms of goat population, India possesses 135.17 million goats and contributes around 26.40 per cent of total livestock population in the country, ranking $2^{\text {nd }}$ in the goat population of the world (19 ${ }^{\text {th }}$ Livestock Censes -2012).

The total livestock population in Rajasthan is about 577.32 lacs. In Rajasthan, the goat's population was $216.66 \mathrm{lac}$ and contributes around 37 per cent of total livestock population in the Rajasthan $\left(19^{\text {th }}\right.$ Livestock Census Rajasthan-2012).

Research area Chittorgarh district has total livestock population is 13, 77,269 lakh. In Chittorgarh district total goat population is $4,74,799$ and contributes around 34.47 per cent $\left(19^{\text {th }}\right.$ Livestock Census Rajasthan-2012). In which Chittorgarh tehsil goat population is 70,328 and contributes around 14.81 per cent whereas, Kapasan tehsil goat population is 64,165 and contributes around 13.52 per cent (Farmers portal, Gram war population- 2012). Hence, the present investigation was undertaken to study the breeding and feeding management practices among livestock owners in Chittorgarh district of Rajasthan.

\section{Materials and Methods}

The present investigation was conducted to study goat scientific health care practices of 120 respondents of 8 villages, VIZ., Keljer, Phusariya, Nalda, Barsingh ka Gurha, Keerion ka Khera, Theparion ka Khera, Moda Khera and Samrathpura in Chittorgarh and Kapasan tehsils of Chittorgarh district of Rajasthan were selected using random sampling technique. The interview schedule was pretested before applying it to the actual respondents. After getting opinion of the goat owners and expert advice the interview schedule was modified and then finally used for the study.

The data were collected through personal interview of the goat owners with the help of well-structured interview schedule. The response to each of the questions in the interview schedule was coded and tabulated respondent-wise in a master table. The qualitative data were quantified accordingly and tabulated to draw meaningful inferences. In the present study appropriate statistical tools was applied. Tentatively it has been planned to apply percentage and frequency, mean, and mean per cent score, rank and chisquare test. Therefore, significance among the different classes will be tested with chisquares test (Snedecor and Cochran, 1994).

\section{Measurement of adoption}

In the present study the term adoption operationalized as the new practice recommended by scientist after thorough research for the benefit of goat owners. Whether the goat owners using these technologies over a period of time at the farm or not. The selection of recommended housing and management practices. The most important recommended practices in each 
aspect were selected on the basis of highest score points in order of merit.

According to selection of recommended scientific housing and management practices, an adoption schedule was developed.

The respondents were asked to give opinion about adoption on the point's continuum i.e. fully, partially and least adopted the practice. These three points were scored as 3, 2, and 1, respectively.

To find out the level of adoption, overall score for each respondent was calculated and respondent were categorized into three groups on the basis of overall score obtained by each respondents;

Low level of adoption $=\quad[X-S . D$.

Medium level of adoption $=[X-$ S.D. to $X$ + S.D.]

High level of adoption $=[X+$ S.D. $]$

Frequency and percentage of respondents in each category i.e., low, medium and high were calculated. The adoption index for each respondent was calculated by using the following formula

Adoption index=

Total adoption score obtained by an individual Maximum obtainable score x 100

To determine the extent of adoption mean per cent score for each sub-practice was worked out and ranked accordingly. In order to find out the difference in adoption level among marginal goat owners, small goat owners and large goat owners about different aspects of scientific housing and management practices.

\section{Results and Discussion}

\section{Adoption of recommended scientific health care practices by the goat owners}

This part of chapter deals with the extent of adoption of recommended goat scientific housing and management practices of goats in research area from 120 respondents are summarized in following sub heads and details information are presented in table 1. Adoption is a mental process. In the modern era new ideas are being invented by goat scientists but all the innovations are not being adopted by many of the members of a social system. Adoption of an innovation depends on many factors viz., awareness knowledge, innovativeness and characteristics of an innovations etc. Keeping this in mind an attempt has been made to know the extent of adoption of improved goat scientific housing and management practices. The results are presented in this section of report.

\section{Adoption of health care practices perceived by the respondents}

The data presented in table 1 reveals that overall first rank was obtained by practicing isolation of sick animals from flock with 81.94 MPS. In which level of adoption Chittorgarh tehsil obtained first rank with 95.56 MPS and Kapasan tehsil obtained second rank with 68.33 MPS in the study area. The disposal of placenta by recommended method obtained overall second rank with 73.89 MPS in which level of adoption Chittorgarh tehsil obtained third rank with 73.89 MPS and Kapasan tehsil obtained first rank with 73.89 MPS in all categories.

Likewise, the adoption related control of in house flies/mosquitoes by suitable disinfectants, regular control of ectoparasitic by the recommended measures, uses of deworming against internal parasites as per recommended, timely vaccination against 
contagious diseases, practicing recommended method of disposal of carcass, proper care and treatment of naval cord at recommended time, practicing hair clipping at proper time, hoof trimming at proper time, treatment of common diseases of goat by veterinarians, use of recommended scientific clean milking procedure, grooming practices for protection of goat from parasites were realized as level of adoption by the respondents and ranked, third, fourth, fifth, sixth, seventh, eighth, ninth, tenth, eleventh, twelfth and thirteenth in the priority of adoption with 67.78 MPS,65.83
MPS, 61.11 MPS, 58.61 MPS, 56.94 MPS, 55.28 MPS, 52.78 MPS, 48.89 MPS, 47.22 MPS and 41.67 MPS and 33.61 MPS respectively in the study area. Lack of awareness regarding grooming practices for protection of goat from parasites had low adoption in the study area. Rai et al., (2013) reported that awareness of adoption levels about improved goat rearing practices such as de-worming and health care. Kumar et al., (2015) reported that health care practices had lowest mean score of adoption.

Table.1 Adoption of scientific health care practices by the goat owners

\begin{tabular}{|c|c|c|c|c|c|c|c|}
\hline \multirow{3}{*}{ S. No. } & \multirow{3}{*}{ Statement } & \multirow{2}{*}{\multicolumn{2}{|c|}{ Chittorgarh }} & \multicolumn{4}{|c|}{$(\mathrm{n}=120)$} \\
\hline & & & & \multicolumn{2}{|c|}{ Kapasan } & \multicolumn{2}{|c|}{ Total } \\
\hline & & MPS & Rank & MPS & Rank & MPS & Rank \\
\hline 1 & $\begin{array}{l}\text { Regular control of ectoparasitic by the } \\
\text { recommended measures }\end{array}$ & 73.33 & IV & 58.33 & III & 65.83 & IV \\
\hline 2 & $\begin{array}{l}\text { Deworming against internal parasites as per } \\
\text { recommended }\end{array}$ & 69.44 & $\mathrm{~V}$ & 52.78 & IV & 61.11 & V \\
\hline 3 & Timely vaccination against contagious diseases & 65.56 & VI & 51.67 & $\mathrm{~V}$ & 58.61 & VI \\
\hline 4 & Disposal of placenta by recommended method & 73.89 & III & 73.89 & I & 73.89 & II \\
\hline 5 & Practicing isolation of sick animals from flock & 95.56 & I & 68.33 & II & 81.94 & I \\
\hline 6 & $\begin{array}{l}\text { Treatment of common diseases of goat by } \\
\text { veterinarians }\end{array}$ & 50.00 & XI & 44.44 & IX & 47.22 & XI \\
\hline 7 & $\begin{array}{l}\text { Use of recommended scientific clean milking } \\
\text { procedure }\end{array}$ & 40.00 & XII & 43.33 & $\mathrm{X}$ & 41.67 & XII \\
\hline 8 & $\begin{array}{l}\text { Proper care and treatment of naval cord at } \\
\text { recommended time }\end{array}$ & 63.89 & VIII & 46.67 & VIII & 55.28 & VIII \\
\hline 9 & $\begin{array}{l}\text { Practicing recommended method of disposal of } \\
\text { carcass }\end{array}$ & 65.00 & VII & 48.89 & VI & 56.94 & VII \\
\hline 10 & $\begin{array}{l}\text { Grooming practice for protection of goat from } \\
\text { parasites }\end{array}$ & 33.33 & XIII & 33.89 & XII & 33.61 & XIII \\
\hline 11 & Hoof trimming at proper time & 56.11 & $\mathrm{X}$ & 41.67 & $\mathrm{XI}$ & 48.89 & $\mathrm{X}$ \\
\hline 12 & $\begin{array}{l}\text { Control of in house flies/mosquitoes by suitable } \\
\text { disinfectants }\end{array}$ & 77.22 & II & 58.33 & III & 67.78 & III \\
\hline 13 & Practicing hair clipping at proper time & 57.22 & IX & 48.33 & VII & 52.78 & IX \\
\hline
\end{tabular}


It was concluded from study in the recommended scientific Health Care practices revealed that isolation of sick animals was highly adopted by the goat owners to check the outbreak of diseases was obtained first rank (81.94 MPS). To improve the adoption of recommended health care practices to be organize training camp about scientific goat rearing.

\section{References}

AHD, (2012). Animal husbandry department, India, $\quad 19^{\text {th }} \quad$ Livestock census-2012, http://dahd.nic.in/dahd/ WriteReadData/Livestock.pdf

AHD, (2012). Animal husbandry department, Rajasthan, $19^{\text {th }}$ Livestock census Rajasthan-2012, animalhusbandry.rajasthan.gov.in./live stock census

AHD, (2015-16). Animal husbandry department, Rajasthan. State livestock development policy. www.animalhusbandry.rajasthan.gov.i $\mathrm{n}$

FAO (2012). FAOSTAT available online statistical database, FAO, Rome. http://www.apps.fao.org/page/collecti ons?subset=agriculture.

Farmers' portal (2015). Department of agriculture and cooperation and farmers welfare, ministry of agriculture and farmers welfare. Government of India, 2 Nov, 2015. Farmers.gov.in

Kumar, V., Singh, B.P., Dutt, T. And Maousami (2015). Adoption behaviour of goat farmers about improved technologies in semi arid zone of Uttar Pradesh. The Indian Journal of Animal Sciences, 85(9): 1037-1041.

Rai, B., Singh, M.K., Dixit, A.K. and Rai, R.B. (2013). Livelihood security through improved goat rearing practices under field conditions. The Indian Journal of Small Ruminants, 19(2): 198-201.

Sathyanarayan, K., Jagadeeswary, V., Murthy, V.C., Ruban, S.W. and Sudha, G. (2010). Socio-economic Status of Livestock farmers of Narasapura Village - A Benchmark Analysis. Veterinary World, 3(5): 215218.

Snedecor, G.W. and Cochran, W.G. (1994). Statistical methods. Journal of Educational and Behavioral Statistics, 19(3): 304-307.

\section{How to cite this article:}

Anil Mordia, M.C. Sharma and Sunil Kumar. 2018. Adoption of Scientific Health Care Practices of Goat Owners in Chittorgarh District of Rajasthan, India. Int.J.Curr.Microbiol.App.Sci. 7(07): 2220-2224. doi: https://doi.org/10.20546/ijcmas.2018.707.260 